\title{
A política matrimonial da dinastia de Avis: Leonor e Frederico III da Alemanha
}

MARIA HELENA DA CRUZ COELHO

Faculdade de Letras da Universidade de Coimbra

Representificaremos, na narratividade deste nosso texto, uma "história de caso". Mas de um caso que, na sua densidade, condensa facetas múltiplas do individual e colectivo, afigurando-se pertinente resgatá-lo do passado para a memória do presente.

Ouçamos as palavras de uma crónica. A pena é do cronista régio Rui de Pina:

"... despois de vistos e examinados os contratos do dito casamento, e assy os poderes que traziam (os procuradores) pera o fazer, o recebimento antre a Emperatriz e o Procurador do Emperador se ordenou de fazer, e fez sollenemente per pallavras de presente nos paços do Duque, que sam junto com Sam Cristovam a hum Domyngo IX. dias d'Agosto de mil e quatrocentos cinquenta e hum, ao qual foram El Rey, e o Yfante Dom Fernando seu Irmaaõ-, e ho Ifante Dom Anrrique seu Tio, e Condes e Perlados e muytos Senhores, e assy foy a Raynha com a Yfante Dona Joana, e com muitas outras donas e donzellas de grande condyçam."'

' Rui de Pina, Chronica do Senhor Rey D. Affonso V, in Crónicas de Rui de Pina, introd. e revisão de M. Lopes de Almeida, Porto, Lello \& Irmão-Editores, 1977, cap. CXXXI. 
Contemplemos agora as formas e personagens de um fresco da catedral de Siena. O pintor é Pintorrichio:

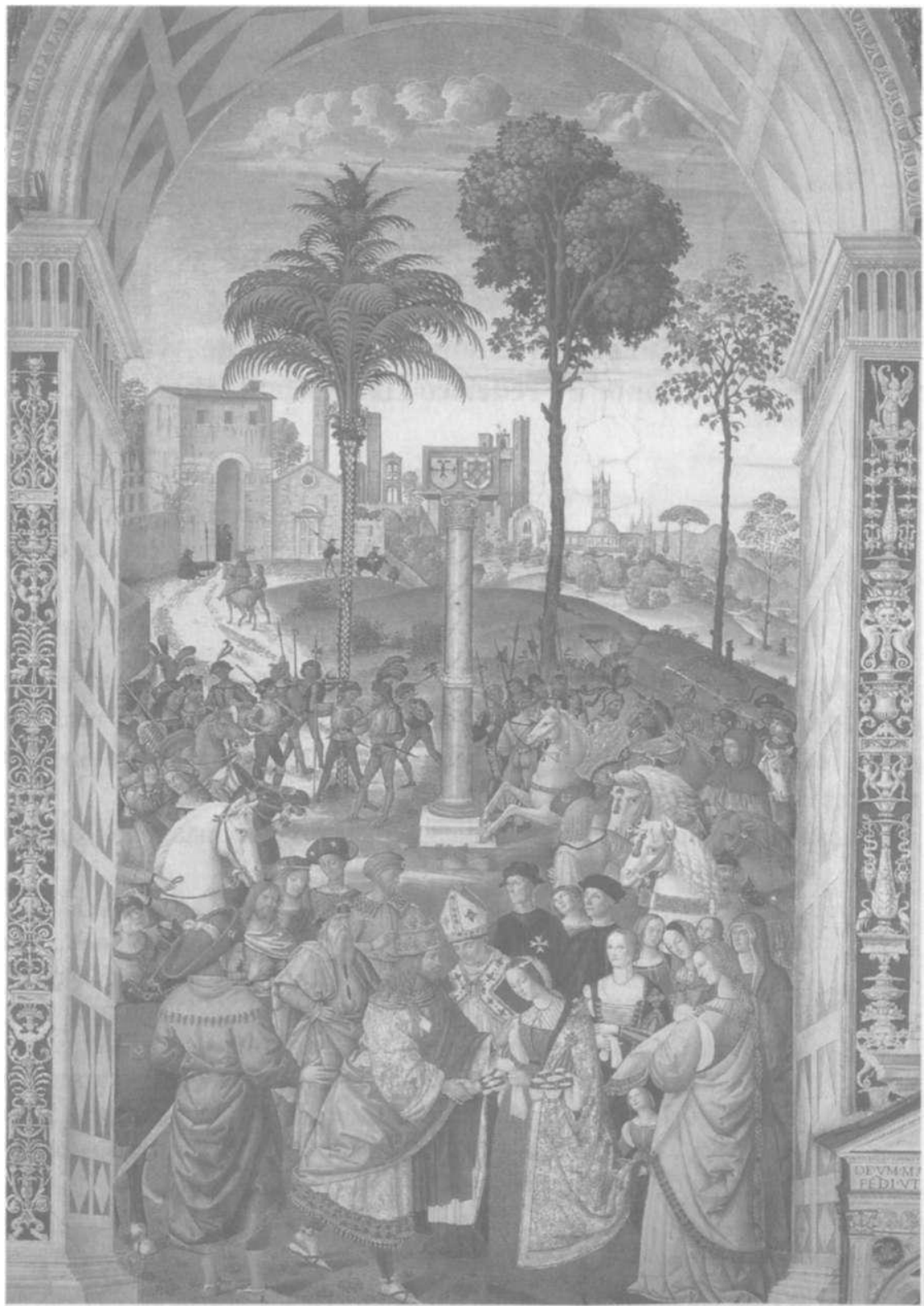

Primeiro encontro de Frederico III e D. Leonor, em Siena 
e eis que deparamos, sob o pano de fundo urbano de uma cidade, uma centralidade média demarcada por um símbolo. Trata-se de um padrão, onde se inscrevem os escudos de Portugal e da Alemanha. Para então nos aproximarmos de um primeiro plano axializado sobre um homem com as insígnias de Imperador e uma bem ataviada senhora, enquadrados ambos pelos seus ricos e vistosos séquitos de cavaleiros e donzelas, os quais, com alguma presteza da parte do homem e um grande encanto e recato por parte da mulher, procedem à immixtum manum, na presença santificadora de um alto dignitário da Igreja, uma figura de bispo.

E assim, pela escrita e pela imagem, desenha-se perante nós, no primeitro quadro, o casamento "por palavras de presente" da infanta D. Leonor de Portugal com o procurador do imperador Frederico III, em Lisboa, a 9 de Agosto de 1451, e, no segundo, o primeiro encontro, ao vivo, dos esposos, na cidade de Siena, onde Frederico III, acompanhado do seu irmão, o duque Alberto, e do seu sobrinho, o pequeno Ladislau, se apressa a ratificar a união, agora com o entrelaçar das mãos direitas, e com o assentimento espiritual de Eneas Sílvio Piccolomini, prelado de Siena. Dois passos do consórcio entre a filha do rei D. Duarte e de D. Leonor de Aragão e o imperador da Alemanha Frederico III ${ }^{2}$ que será a estirpe fundadora da casa dos Habsburgo de onde, a partir de Maximiliano I, descenderão todos os membros da família imperial da Austria-Hungria, como o grande imperador Carlos $\mathrm{V}^{3}$, que também acabará por casar com uma infanta portuguesa ${ }^{4}$. Na realidade, a dimensão política do matrimónio da princesa portuguesa com o imperador alemão pode bem aferir-se pelas numerosíssimas fontes - documentais, literárias e iconográficas - sobre ele produzidas, que, felizmente, até nós chegaram. Por certo nenhuma união da família real portuguesa ficou tão bem documentada, prova cabal do seu magno significado.

${ }^{2}$ Sobre a ascendência de Frederico III, filho de Ernesto da Áustria e nascido a 21 de Setembro de 1415, e a sua chegada ao poder, leia-se Antonia Hanreich, "D. Leonor de Portugal, esposa do Imperador Frederico III (1436-1467)", in Relações entre a Áustria e Portugal. Testemunhos Históricos e Culturais, dir. de Ludwig Scheidl e José A. Palma Caetena, Coimbra, Livraria Almedina, 1985, p. 4 e Luciano Cordeiro, Portugueses fora de Portugal. Uma sobrinha do Infante, Imperatriz da Allemanha e Rainha da Hungria, Lisboa, Imprensa Nacional, 1894, p. 59.

${ }^{3}$ A divisa de Frederico III era A. E. I. O U. (Austriae est imperare Orbi Universo) que plenamente se realizou com Carlos V (E. A. Strasen, Alfredo Gândara, "Uma Portuguesa Imperatriz da Alemanha", in Oito séculos de História Luso-Alemã, Lisboa, Instituto Ibero-Americano de Berlim, 1944, p. 73).

A contextualização do matrimónio da infanta Isabel, filha de D. Manuel, com o Imperador Carlos V é estudada por Margarida Sobral Neto, no trabalho, "La Emperatriz Isabel. Una hija del Rey de Portugal en la Corte de Carlos V", Correspondence, número especial, 1994, pp. 69-77. 
A dinastia de Avis, que tem a sua matriz fundacional na escolha, que não sucessão, de um rei, para mais um bastardo, procurou legitimar-se no ser e parecer. Entreteceu-se pelos laços de família, cultivou-se nas letras e ciências, engrandeceu-se por valorosos feitos guerreiros, santificou-se pela moral e bons costumes e até mesmo pelo martírio. Os actos fundamentaram, desde a raiz, essa árvore genealógica de ilustres vergônteas. D. João I o os infantes de Avis, a ínclita Geração, assumem-se e representam-se com uma família unida, santa e cultas. Ela se fez ao mar e conquistou Ceuta, como mais tarde Arzila e Tânger, cristianizando o Norte de África. Esforçou-se por povoar e humanizar espaços virgens e selvagens, como os das ilhas da Madeira, Açores, Cabo Verde e S. Tomé e Príncipe. Afrontou mitos e lendas e sulcou o oceano Atlântico, aproveitando-se das riquezas que a África lhe oferecia e, agigantando-se, deu a conhecer ao mundo uma estrada marítima para a índia. Perenizou-se pela escrita em obras sobre a montaria e equitação ou sobre a moral e valores da nobreza. Santificou-se no exemplum de uma família unida e devota, na morte redentora pela pátria de um dos seus infantes e na santidade monástica de uma das suas princesas. Imortalizou-se pela arte, reunindo-se, depois da morte, num mesmo panteão dinástico, o mosteiro da Batalha, penhor de uma memória régia plurissecular'. Enalteceu-se graças a uma propaganda política suportada por ritos, cerimoniais, crónicas, poesias, retratos e túmulos, representações simbólicas do prestígio, feitos, valores e imorredouro poder da realeza. Enfim, redimensionou-se e ancorou-se no variegado xadrez político da cristandade, graças a uma ponderada e sábia diplomacia. Diplomacia orquestrada com diversos meios e agentes, mas superiormente dirigida pelo jogo político das alianças matrimoniais?.

Um casamento entre as famílias nobres era, como se sabe, um acto de estratégia familiar e patrimonial, de transmissão e valorização da linhagem e de resguardo ou engrandecimento da riqueza herdada. Mas entre as famílias régias era, para além de tudo isso, e predominantemente, um acto político ${ }^{8}$.

Luís Adão da Fonseca, "Una elegia inédita sobre la família de Avis. Un aspecto de la propaganda política en la Península Ibérica a mediados del siglo XV", Anuario de Estudios Medievales, 16, Barcelona, 1986, pp. 449-463.

Sobre este panteão leia-se Saul António Gomes, "Percursos em torno do panteão quatrocentista de Avis", in Vésperas Batalhinas. Estudos de História e Arte, Leiria, Magno Edições, 2000, pp. 16-66.

Os traços desta ampla política diplomática são apontados por Luís Adão da Fonseca, na obra, Os Descobrimentos e a Formação do Oceano Atlântico. Século XIV- século XVI, Lisboa. CNCDP, 1999, pp. 50-62, destacando as uniões matrimoniais, sobremaneira, nas páginas 58-59.

"Christopher Brooke, O casamento na Idade Média, trad. port., Lisboa, Publicações Europa- América, 1991, pp. 109-114. 
Com as uniões matrimoniais buscavam-se os aliados, no intuito de um reforço do poder político, que se queria firmado no interior de um reino, mas maximamente projectado na constelação internacional das realezas. Um casamento, mais do que qualquer outro acto diplomático, unia partidos ou casas reais, não apenas pelo vínculo político, mas pelo vínculo de sangue, dos herdeiros e das heranças. Matrimónio fértil era, pois, laço político indestrutível, para o bem, numa conseguida aliança, ou para o mal, se os objectivos se malograssem. Acto talvez só remediável com uma nova aposta de consórcio matrimonial por entre outras casas reinantes.

Ponderadamente, o rei fundador de Avis pensou as estratégias matrimoniais da sua linhagem?. Antes de mais planeou a sua própria, consorciando-se com D. Filipa de Lencastre, revivificando a sua preferencial aliança com a Inglaterra, para se fortalecer, também por essa via, face ao poderio castelhano. Os infantes diversificaram, porém, a rede internacional de apoios ao escolherem as suas noivas. O herdeiro do trono, D. Duarte, congraçou-se com outro tradicional aliado de Portugal, o reino de Aragão, matrimoniando-se com D. Leonor. O infante D. Pedro também aí, ainda que em facção rival, buscou a sua noiva, unindo-se a Isabel, filha do conde de Urgel. A infanta D. Isabel comprometer-se-á com o duque de Borgonha, Filipe, o Bom, facilitando ao reino português as relações económicas, diplomáticas e artísticas com muitas casas reais europeias. Finalmente a filha ilegítima de D. João I, D. Brites, protagonizará dois matrimónios internacionais, um com o conde de Arundel e outro com o barão de Irchenfield. A casa de Avis viu-se, assim, enlaçada, pelo sangue, com a coroa inglesa e aragonesa e com o ducado da Borgonha, entre outros.

Esta estratégia política, que o próprio movimento expansionista impulsionava, abriu os membros da linhagem aos mais variados caminhos por entre os meandros da política dos reinos da cristandade. Assim a diáspora dos herdeiros do infante D. Pedro - o Condestável e Mestre de Avis, D. Pedro, veio a ser, por alguns anos, rei de Aragão; D. João, pelo seu casamento com a rainha de Chipre, Catarina de Lusignan, tornou-se príncipe de Chipre; já D. Jaime ascenderá a cardeal de Santa Maria in Portico; e D. Beatriz unir-se-á a Adolfo von Kleve. Por sua vez, o infante D. João, Mestre de Santiago, e sua mulher Isabel, filha do conde de Barcelos e duque de Bragança e de D. Brites Pereira, descendente de Nuno Álvares Pereira, serão os pais da infanta Isabel que desposará D. João II, rei de Castela, de quem nascerá Isabel, a Católica ${ }^{10}$.

' Para um completo esclarecimento destas uniões, veja-se a genealogia da dinastia de Avis apresentada por A. H. de Oliveira Marques, Portugal na crise dos séculos XIV e XV, Lisboa, Editorial Presença, 1987, entre as páginas 528 e 529.

${ }^{10}$ A. H. de Oliveira Marques, ob. cit., p. 562. 
Situemo-nos, porém, agora, na linhagem do sucessor ao trono joanino, D. Duarte. Teve este monarca, do seu matrimónio com Leonor de Aragão, quatro filhos e quatro filhas. O herdeiro virá a ser o seu terceiro rebento, Afonso, que é ainda menor quando recebe o reino, em 1438. Cabendo a tutoria da criança e a regência do reino, por vontade de D. Duarte, expressa no seu testamento, à viúva D. Leonor de Aragão, esta situação política não foi bem aceite. Temiam-se uns quantos desta rainha estrangeira, que podia defender mais interesses outros externos e menos os de Portugal, e não viam com bons olhos a educação do príncipe entregue a uma mulher. Decidiram, então, os grandes do reino e a burguesia lisboeta entregar a regência do reino e a tutoria do herdeiro ao seu tio mais velho, o infante D. Pedro. Que será regente de 1439 a 1448, para, no ano de 1449 , já afastado da corte, vir a acabar os seus dias em trágicas circunstâncias". Esta contextualização política é fundamental para nos aproximarmos de D. Leonor, a futura esposa do imperador alemão.

Nasceu a infanta em Torres Vedras, a 18 de Setembro de 1434. Ficou órfã de pai aos quatro anos e um ano depois viu-se sem mãe, quando esta, ao exilar-se para Castela, a deixou doente em Almeirim. O regente assume, então, as rédeas do seu destino e entrega-a a uma aia, D. Guiomar de Castro ${ }^{12}$. Mais tarde, após a morte da mãe, em 1445, terá vivido em casa própria, com as suas irmãs Catarina e Joana ${ }^{13}$. Este conjunto de infantas era riqueza a ser potencia-

"Sobre este regente veja-se a completa obra de Humberto Baquero Moreno, A batalha de Alfarrobeira. Antecedentes e significado histórico, 2 vols., Coimbra, Biblioteca Geral da Universidade, 1979,1980 e, para a contextualização do infante em Coimbra, leia-se Maria Helena da Cruz Coelho, "O Infante D. Pedro, duque de Coimbra", Biblos, vol. LXIX, 1993, pp. 15-57.

${ }^{12}$ Rui de Pina, Chronica do Senhor Rey D. Affonso V, cap. LXVI. Guiomar de Castro, filha de D. Pedro de Castro e de D. Leonor Teles de Meneses, era casada com D. Alvaro Gonçalves de Ataíde, aio do pequeno rei, o qual veio depois a ser Conde de Atouguia. Em boa parte fomentados por este laço entre D. Leonor e D. Guiomar, fala-se dos amores de um seu parente, João de Meneses da Silva (filho de Rui Gomes da Silva e de Isabel de Meneses) pela infanta. Este, depois do casamento de Leonor, teria então procurado abraçar a vida religiosa, vindo a ser franciscano e a tomar o nome de frei Amadeu. Foi confessor e conselheiro do papa Sisto IV e fundou, entre outros, o mosteiro de S. Pedro de Montorio, em Roma, e o de Nossa Senhora da Paz, em Milão, onde veio a falecer, com fama de santidade, em 10 de Agosto de 1482 (Luciano Cordeiro, ob. cit., pp. 41-42; António José Saraiva, O crepúsculo da Idade Média em Portugal, Lisboa, Gradiva, 1990, pp. 83-83).

${ }^{13}$ E sabemos haverem sido serviçais de D. Leonor (embora desconheçamos exactamente em que contextos e épocas), Beatriz Pereira, Branca de Lira, D. Violante Lopes, Maria Rodrigues, Catarina Lopes Bulhoa, Diogo de Torres e Fernão de Torres, além de se conhecer que era seu confessor um protonotário de nome desconhecido (Sousa Viterbo, "D. Leonor de Portugal, Imperatriz da Allemanha. Notas documentaes para o estudo biographico d'esta princesa e para a historia das relações da corte de Portugal com a Casa d'Austria", Archivo Historico Portuguez, VIII, Lisboa, 1910, pp. 43,46). 
lizada em conjugada e hábil política matrimonial. Concertam-se neste propósito os dois tios das infantas - a duquesa de Borgonha e o regente D. Pedro. A Borgonha conhecia dois suseranos, o rei de França e o Imperador da Alemanha. Buscou com eles alianças matrimoniais que a favorecessem. Projectou então a duquesa o casamento da sua sobrinha Leonor com o herdeiro do trono da França e oferecia a mão da sua outra sobrinha, Joana, ao pequeno Ladislau, neto do imperador Segismundo, ao serviço de quem D. Pedro lutara contra os turcos, e que Frederico III havia tomado sob a sua tutela ${ }^{14}$. Esta estratégia matrimonial serviria também os objectivos políticos do regente D. Pedro, que, hostilizado e hostilizando os infantes de Aragão, se aliava a Castela e assim alargaria os seus apoios a França e ao Império.

Não foram, porém, estes agentes, mas justamente os da facção contrária, que vieram a concretizar a aliança com o Império. Nem foram tão-pouco aquelas as peças jogadas. Em vez de Joana e Ladislau serão Leonor e o próprio imperador Frederico III a entrarem em cena.

Em Julho de 1448, o infante D. Pedro deixa o regimento do reino a D. Afonso V e retira-se para o seu ducado de Coimbra. Ora, por cartas da rainha de Aragão de 14 de Outubro de $1448^{15}$, que recomendava aos reis e rainhas de Castela, Portugal e Navarra e ao duque e duquesa de Coimbra os embaixadores de Frederico III a Portugal, o barão austríaco Jorge de Volrestorf e o cónego de Augsburg Ulderico Riedrer ${ }^{16}$, sabemos que o próprio imperador tinha em vista contrair matrimónio com uma infanta deste reino, que se afamava com a expansão ultramarina e avultava cada vez mais nas rotas comerciais ${ }^{17}$. Mas as rédeas da acção estariam já em poder do rei e rainha de Aragão, os adversários do infante D. Pedro, que se concertavam com o principal parceiro

${ }^{14}$ E assim se pacificariam também os duques da Borgonha com Ladislau, a quem haviam tomado, pela força, Luxemburgo, sua pertença (Luciano Cordeiro, ob. cit., p. 34).

${ }^{15}$ Monumenta Henricina, dir, org. e anotação critica de António Joaquim Dias Dinis, vol. IX (1445-1448), Coimbra, 1968, docs. 203-206.

${ }^{16}$ E. A. Strasen, A. Gândara, "art. cit.", p. 69, diz que com eles veio um pintor, que não se conhece, para fazer o retrato de D. Leonor, que era lindíssima. Luciano Cordeiro, ob. cit., p. 37 propõe que ele fosse talvez da escola austríaca de Colónia e explica que tais retratos eram necessários porque, tendo os casamentos como objectivo a procriação e continuação dinástica, procuravam desvendar-se, nas formas e feições do retrato, as capacidades orgânicas da mulher para tais funções. Sobre a abundante iconografia desta princesa - pintores, moedas e estátuas espalhada por várias cidades europeias, veja-se o estudo de Henrique de Campos Ferreira Lima, "D. Leonor de Portugal, filha d'el-rei D. Duarte, imperatriz da Alemanha", Revista de História, 10(37-40), Lisboa, 1921, pp. 143-150.

${ }^{17}$ Antonia Hanreich, "art. cit.", p. 5 refere anteriores projectos do imperador se matrimoniar com uma princesa francesa, com a filha do anti-papa Félix $\mathrm{V}$ e com a viúva do rei Alberto II, Isabel. 
deste jogo de alianças, o irmão da infanta, o rei de Portugal, Afonso V. Afonso, o Magnânimo, rei de Aragão e de Nápoles, apadrinha este matrimónio tendo em vista a segurança das suas possessões italianas, sempre ameaçadas por França e pelo Papado, e o reforço do seu poder no reino de Aragão ${ }^{18}$. Não menos, como já foi notado, se assume, em grande parte, como o tutor dos filhos de sua irmã, em especial de D. Leonor, a quem diz amar, não como uma sobrinha, mas como filha ${ }^{19}$. O monarca português, se bem que talvez preferisse a união de uma das suas irmãs com o Delfim da França, não negligenciaria, como outra hipótese possível, o reforço dos seus laços com Aragão e a creditação do seu poderio e prestígio pela união da casa de Portugal com o Império ${ }^{20}$. Para, alguns anos mais tarde, em 1455, sedimentar ainda mais as suas redes de apoio peninsulares ao casar a sua irmã Joana com Henrique IV de Castela.

Entretanto, no reino português, os acontecimentos precipitam-se. Agudizam-se as facções opostas do duque de Coimbra e do duque de Bragança, manobrando este intensamente na corte, junto do monarca. Cresce a tensão e o ódio entre partidos rivais. O desenlace será o enfrentamento militar entre a hoste régia e a de D. Pedro, no campo de Alfarrobeira, que terá, como epílogo, a morte do infante, em Maio de 1449. Os seus partidários serão considerados traidores, vendo os bens confiscados. A tristeza e a dor toldariam os ânimos de alguns portugueses. Nada melhor para que D. Afonso V se impusesse, acima de tudo e de todos, que oferecer ao reino um magno e prestigiado acontecimento. A semente estava lançada com a prévia embaixada do imperador da Alemanha. O fruto amadurecido colher-se-á com muita alegria por dentro de um elaborado cerimonial e uma ostentatória pompa.

Os esponsórios de D. Leonor de Portugal com Frederico III, imperador da Alemanha, serão, a todos os títulos modelares, segundo os cânones civis e eclesiásticos. Para servirem de exemplum legitimador do rei de Portugal e dos Algarves e senhor de Ceuta e do imperador, rei dos Romanos.

${ }^{18}$ Sobre as relações de Afonso V, rei de Nápoles desde 1442, com o Papado, leia-se Vicente Ángel Álvarez Palenzuela, "Alfonso V, rey de Nápoles: regulación de la sucesión y reconciliación con el Pontificado", in Actas do XV Congreso de Historia de la Corona de Aragon, "El Poder Real en la Corona de Aragon (siglos XIV-XVI) ", t.I, 1998, pp. 511 -522.

Assim o afirma numa carta enviada a $D$. Leonor, em 18 de Janeiro de 1451, em resposta a outra que a infanta lhe mandara por João Fernandes da Silveira, dando-lhe conta do bom andamento da embaixada para o seu casamento, em que se lê. "vos haueremos en recomendación, no solamente de sobrina, mas de propria fija, por el amor que vos hauemos" (Monumenta Henricina, vol. XI (1451-1454), Coimbra, 1970, doc. 1).

${ }^{20}$ Luciano Cordeiro, ob. cit., pp. 35-37. 
O casamento assumia-se, nestes finais da Idade Média, como uma união sacramental que devia decorrer sob a benção da Igreja. Acto de vontade dos nubentes, em que, no pleno uso da liberdade, tão cara a estes alvores da modernidade, se lhes exigia o respectivo consentimento. Comummente aceite era já então a ideia de que a plena efectivação do matrimónio ocorria só com a sua consumação ${ }^{21}$. Mas as uniões régias exigiam mais delongas e não excluiam sequer o consensus, no verdadeiro sentido da palavra no direito romano, o acordo dos progenitores, que, como vimos, verdadeiramente o ditava. E depois havia de ser formalizado o contrato nupcial, com a especificação das doações que em tal ocasião eram devidas.

Tudo conhecemos, com pormenor, nos esponsórios de Leonor com Frederico III. Talvez fruto da primeira embaixada alemã a Portugal, as ideias clarificaram-se. Arredou-se do pensamento afonsino a hipótese do casamento da irmã com o herdeiro da França e prefigurou-se a união com o Imperador da Alemanha. Aliás, segundo parece, Leonor exprimiu a sua própria vontade, declarando que só se casaria com a majestade imperial e cesárea ${ }^{22}$. Nas Cortes de Santarém de 1451, o monarca consultou as forças sociais do reino sobre este enlace, que foi aceite, sendo outorgados à coroa, para a sua despesa, dois pedidos e meio e uma dízima e meia ${ }^{23}$.

Parte então para Nápoles, em Junho, o procurador do soberano, João Fernandes da Silveira ${ }^{24}$, pois, aí, segundo a vontade do imperador, seria acordado o contrato

${ }^{21}$ Assim se diz explicitamente num passo do contrato nupcial: "matrimónio ajustado e, por mão de Deus, a concluir-se e celebrar, depois, auspiciosamente, à face da Santa Madre Igreja por palavras de presente e, finalmente, por vontade do Altíssimo, a consumar por solenes núpcias e união carnal" (Princesas de Portugal. Contratos matrimoniais dos séculos XV e XVI, ed. do texto latino e tradução de Aires A. Nascimento, colaboração de Maria Filomena Andrade e Maria Teresa Rebelo da Silva, Lisboa, Edições Cosmos, 1992, p. 67). Leia-se, a este propósito. Christopher Brooke, ob. cit., pp. 114-128.

${ }^{22}$ Antonia Hanreich, "art. cit.", p. 13.

${ }^{23}$ Armindo de Sousa, As Cortes Medievais Portuguesas (1385-1490), vol. I, Porto, 1N1C, 1990, pp. 372-374.

${ }^{24}$ Sobre o percurso de vida do Doutor João Fernandes da Silveira, filho do desembargador e chanceler-mor do reino no tempo de D. João I, Doutor Fernando Afonso Silveira, e de Catarina Teixeira, Doutor em Leis e também ele desembargador, vice-chanceler, chanceler-mor interino, chanceler da Casa do Cível e Regedor da Casa da Suplicação nos governos do regente e de D. Afonso $V$ e depois escrivão da puridade, chanceler-mor e vedor da Fazenda do príncipe D. João e muitas vezes embaixador, além de deter vários outros cargos, veja-se Judite Antonieta Gonçalves de Freitas "Teemos por bem e mandamos": A burocracia régia e seus oficiais em meados de Quatrocentos (1439-1460), vol. 11, Catálogo prosopográfico dos redactores. Cascais, Patrimonia Historica, 2001, pp. 437-442. 
nupcial, sob os auspícios de Afonso, o Magnânimo ${ }^{25}$. Reúne-se, então, com os procuradores de Frederico III, D. Eneas, bispo de Trieste, D. Jorge de Vollesdorff, barão do ducado de Áustria, seus conselheiros, e Miguel de Phullendorf, se u secretário. O contrato virá a ser outorgado a 10 de Dezembro de $1450^{26}$, na presença de autoridades ilustres, como o duque da Calábria e de Clèves e os embaixadores das repúblicas de Veneza e Florença. Declaravam-se, inicialmente, as etapas do casamento - naquele momento ele ficava desde logo ajustado por palavras de futuro, para depois ter lugar, no espaço de seis meses, por palavras de presente, à face da Santa Madre Igreja. O dote da noiva seria de 60000 florins de ouro de câmara, correntes na cúria romana, sendo as arras do noivo (donatio propter nuptias) do mesmo valor, segundo os costumes da Alemanha. Ficava ao critério do imperador a doação matutina \{donationem matutinam in crastinum scilicet nuptiarum), um acréscimo simbólico à "compra do corpo virgem" da noiva, o verdadeiro "dom da manhã", após a consumação do acto, dos costumes germânicos ${ }^{27}$. O dote, satisfá-lo-ia o rei de Portugal, em Bruges, na Flandres, ou em Florença, na Itália, conforme o determinasse o rei dos Romanos, no prazo de 15 meses após a consumação do matrimónio, devendo ser-lhe descontados 10000 florins, que se afectavam às despesas de viagem da noiva ${ }^{28}$. O imperador comprometia-se a discriminar os bens cujos réditos reverteriam para a infanta, no espaço de quatro meses, o que de facto virá a concretizar, por carta de 16 de Março de $1451^{29}$, afectando-lhe o vicedomínio de Laibach, no ducado de Carníola, o castelo e vila de Bliburgo, no ducado de Caríntia, e o castelo de Stuchsenstein, no ducado de Áustria ${ }^{30}$. A segurança da noiva, neste acto de

${ }^{25}$ Rui de Pina, Chronica do Senhor Rey D. Affonso V, cap. CXXXI.

${ }^{26}$ Princesas de Portugal, pp. 63-83. Havendo o procurador do rei de Portugal chegado em Outubro de 1450, apercebemo-nos que as negociações prévias do contrato foram muito ponderadas, alongando-se por quarenta dias (Antonia Hanreich, "art. cit", p. 14).

${ }^{27}$ Maria Helena da Cruz Coelho e Leontina Ventura, "A mulher como um bem e os bens da mulher", sep. de Actas do Colóquio "A Mulher na Sociedade Portuguesa", Coimbra, 1986. p. 12, sendo também de recorrer à bibliografia sobre o matrimónio aí citada.

${ }^{28}$ A efectivação deste dote foi-se arrastando e o mesmo só ficará inteiramente satisfeito ma is de trinta anos depois do casamento, por actos ocorridos entre D. João 11 e seu primo Maximiliano, como bem o demonstra a ampla documentação apresentada por Sousa Viterbo, "D. Leonor de Portugal...", Archivo Historico Portuguez, VIII, pp. 36-41.

${ }^{29}$ Princesas de Portugal, pp. 88-93.

30 Mais tarde, a 24 de Agosto de 1452, pormenoriza-se que os alcaides respondiam por tais castelos e terras perante Lopo de Almeida e João Fernandes, embaixadores do rei de Portugal (Princesas de Portugal, pp. 94-95). De facto estes portugueses acompanharam a imperatriz até à Alemanha e sabemos até que Lopo de Almeida estava mandatado pelo monarca para activar as relações comerciais luso-alemãs, mormente quanto ao trato do sal (A. H. de Oliveira Marques. Hansa e Portugal na Idade Média, 2" ed., Lisboa, Editorial Presença, 1993, p. 71). 
passagem, traduzia-se no montante de 120000 florins, usufruindo a infanta plenamente de bens nesse valor para manter a sua honra e estado ${ }^{31}$. A infanta devia estar em Itália até inícios de Novembro, vinda por mar, desembarcando no porto que o imperador determinasse, entre Pisa e Nápoles. Tudo foi jurado, sob a palavra de honra dos procuradores e o testemunho de Deus, pondo eles as mãos nos Evangelhos, assim comprometendo o nome e a alma dos seus reis. Mais inexoravelmente comprometendo a vida futura de D. Leonor, escandida, toda ela, por marcantes e simbólicas passagens.

Acordado deste modo o casamento por palavras de futuro, imperioso era avançar para o passo seguinte, a sua efectivação por palavras de presente. Por carta de 14 de Março de $1451^{32}$, o rei dos Romanos credita como procuradores, para tal acto, os seus capelães Tiago Motz, bacharel em Teologia, e Nicolau de Valckenstein. Embaixada assaz reduzida e pobre para um imperador, comojá tem sido amplamente notado, bem expressiva de alguns dos seus traços de carácter, como a parcimónia, se não mesmo a avareza, acumulada da astúcia, já que pelo estado eclesiástico dos seus procuradores justificava a humildade da delegação ${ }^{33}$. Como se sabe, o capelão Nicolau Lanckmann de Valckenstein escreveu um diário sobre a sua viagem até Portugal e depois sobre as festas do casamento da infanta D. Leonor no reino e a sua viagem por Itália até chegar à Alemanha, intitulado Historia Desponsationis Frederici III cum Eleanora Lusitanica".

Somos então informados que a jornada dos embaixadores alemães foi atormentada, atravessando o ducado de Sabóia (com ida a Genebra), o reino de França (aí visitando Chartreuse, Saint-Antoine, Montpellier, Toulouse) e seguindo depois por Narbona e Perpignão para a Catalunha. Já na Península

${ }^{31}$ Por isso minuciosamente se especificam os quadros da herança destes bens por morte dos cônjuges, acrescentando-se ainda qua a infanta podia levar de Portugal, para seu acompanhamento e serviço, homens ou mulheres, mas a sua aceitação e número ficavam ao critério do Imperador.

${ }^{32}$ Princesas de Portugal, pp. 84-87.

${ }^{33}$ Antonia Hanreich, "art. cit.", p. 15.

${ }^{34}$ Publica-se esta fonte em António Caetano de Sousa, Provas da História Genealógica da Cusa Real Portuguesa, nova edição, t. I, liv. III, Coimbra, Atlântida, 1947, pp. 329-370, a qual Luciano Cordeiro, ob. cit., traduz das páginas 95 a 149. Mais recente é porém a edição bilingue Leonor de Portugal Imperatriz da Alemanha. Diário de viagem do embaixador Nicolau Lanckman de Valckenstein, edição do texto latino e tradução de Aires A. Nascimento com colaboração de Maria João Branco e Maria de Lurdes Rosa, Lisboa, Edições Cosmos, 1992, texto que seguiremos. Foi a partir dele que elaborámos os dois mapas que neste estudo se apresentam. Agradecemos vivamente ao Mestre Anísio Miguel de Sousa Bem-Haja Saraiva que, com as nossas orientações, se encarregou da cartografia dos itinerários. 


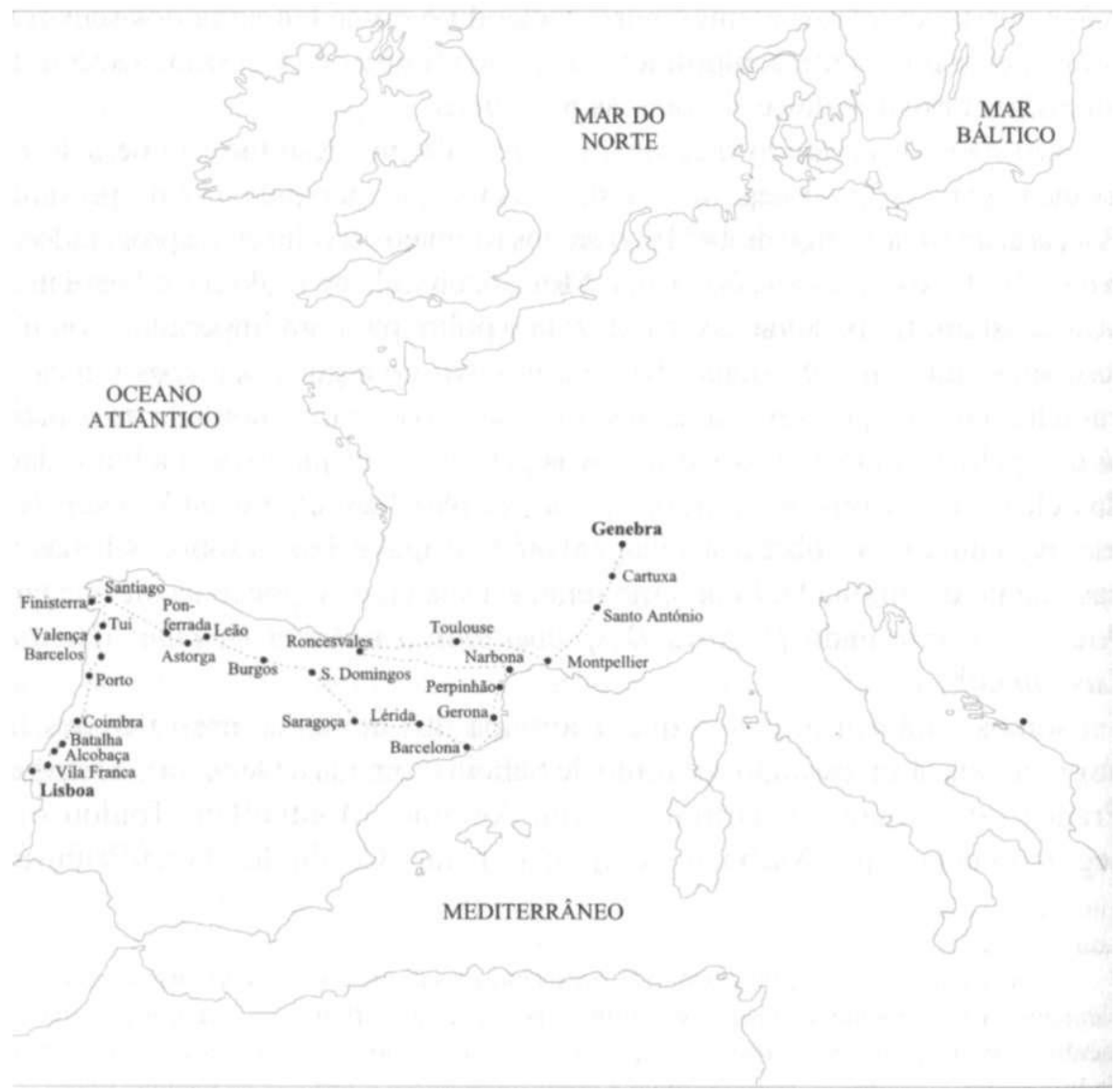

percorreram os reinos de Aragão, Navarra, Castela e Leão, passando por Gerona, Barcelona, onde receberam salvos-condutos da rainha de Aragão, Saragoça, S. Domingos (de la Calzada, próximo de Logronho), Burgos, Leão e Astorga. Aqui, havendo guerra, disfarçaram-se de peregrinos e avançaram para a Galiza, mas acabaram por ser atacados, ficando sem roupa, dinheiro, cavalos e até mesmo sem as cartas do imperador. Chegaram assim a Ponferrada, onde um 
conde lhes emprestou dinheiro ${ }^{35}$ e, por fim, a Santiago de Compostela ${ }^{36}$. Entraram em Portugal por Valença e passaram por Barcelos, Arrifana de Santa Maria (?) ${ }^{37}$, Porto, Coimbra, Batalha (para homenagearem os antepassados de Leonor), Alcobaça, chegando a Vila Franca (?) e Lumiar (? ${ }^{38}$. Esperaram aí pelo chamamento de D. Afonso $\mathrm{V}$ e quando entraram em Lisboa anotaram, desde logo, que era "uma cidade notável, e muito maior que Viena de Áustria" ${ }^{39}$. Foram levados até ao paço real no castelo, em cortejo luzido de senhores, bispos, prelados, condes, barões e cavaleiros nobres, para além de uma deputação de mouros e da câmara da cidade e muito povo, aí deparando com o monarca sentado no trono em toda a sua majestade: "em sua cadeira triumfante posto em seu estrado Real" ${ }^{40} .0$ soberano, na expressão da sua liberalidade, determinou-lhes que repousassem um certo tempo nos Estaus, para se recomporem das agruras da jornada. Alguns dias depois, conduziu-os pessoalmente o monarca até ao paço da rainha, que com eles conversou, para visitarem então o paço das infantas, onde os embaixadores conheceram, para além de D. Catarina e D. Joana, a prometida do imperador, reunindo-se todos, em conversações e danças, no paço real. Terminou, enfim, o dia com um conselho régio, relatando os procuradores a vontade imperial de, por eles, ser contraído o matrimónio por palavras de presente.

Este, como o dissemos ao abrir, concluiu-se logo a 9 de Agosto ${ }^{41}$ perante o casal real, infantas, príncipes, condes, barões e ilustres nobres "por palavra de presente com arenga apropriada, Adorna thalamum, etc, segundo o ritual,

${ }^{35}$ Empréstimo contra uma letra a ser paga em Santiago de Compostela, onde podiam negociar a ordem de Cosme de Médicis sobre Florença, atestando bem o centro internacional de peregrinações que era, ao tempo, Santiago.

A viagem destes embaixadores, no enquadramento dos caminhos e actos relacionados com a peregrinação de Santiago, apresenta Klaus Herbers, no seu estudo "El viaje a Portugal de los embajadores de Federico III en el relato de Lanckmann y de otros cronistas", Anuario de Estudios Medievales, 32/1, Barcelona, 2002, pp. 183-198, aí se apresentando também ampla bibiografia alemã sobre esta união imperial.

${ }^{37}$ A descrição de Lanckmann não refere esta terra. Todavia, Rui de Pina. Chronica do Senhor Rey D. Affonso V, cap. CXXXI relata que, neste lugar, os encontrou o bispo de Coimbra, que os terá provido de dinheiro e servidores e ainda de panos em Coimbra.

${ }^{38}$ É ainda tão-só Rui de Pina que conta terem os embaixadores sido muito bem recebidos pelo infante D. Henrique, em Vila Franca, indo depois dormir ao Lumiar, a 30 de Julho.

" Leonor de Portugal..., p. 29.

" Rui de Pina, ob. cit., cap. CXXXI; Leonor de Portugal..., p. 29: "O sereníssimo senhor rei de Portugal estava no seu trono, de coroa e ceptro, cercado dos seus ilustres fidalgos, cavaleiros, barões, etc, engalanados ricamente de acordo com a sua hierarquia".

" Esta é a data que apresenta Rui de Pina. Já na descrição de Lanckmann se afirma que o monarca os recebera a 1 de Agosto e que o casamento tivera lugar no dia seguinte. 
com ósculo na face, e entrega do anel", como refere Lanckmann ${ }^{42}$. E logo soaram as trombetas e, no novo paço onde se instalou a imperatriz, o de S. Cristóvão, houve danças e festas e sabores de vinho e fruta. Por sua vez, enquanto o monarca, a pedido da irmã, distribuía cartas de perdão e de quitação de dívidas ${ }^{43}$, nas igrejas e mosteiros da cidade erguiam-se orações e organizavam-se procissões de acções de graças pelos esponsais, para já nas ruas se ouvirem vozes que aclamavam: "viva a senhora imperatriz, a senhora desposada, Dona Leonor" ${ }^{44}$. Mas antes da partida da infanta desenrolaram-se longos festejos, talvez os maiores até então empreendidos por um monarca de Avis, por entre banquetes, desfiles, cortejos históricos, danças, representações teatrais, momos, justas, jogos de canas, touradas e caçadas, que decorreram de 13 a 25 de Outubro de $1451^{45}$.

No primeiro dia teve lugar um desfile com reis de armas e arautos que, em nome das rainhas da Cristandade, apresentavam saudações à Senhora Imperatriz. Seguiam-se mouros e etíopes, exibindo os seus trajes e danças, e puxando um dragão. Brilhava depois o corpo de cavaleiros do infante D. Fernando, chefiado pelo seu senhor. Para logo se prenderem os olhos no exotismo do desfile de indígenas das Canárias, atingindo-se o clímax com a apresentação do próprio monarca e seus guerreiros, belamente guarnecidos, que se diziam terem vindo de longe para abrilhantar as festas nupciais com os seus feitos de armas. Fechava o cortejo uma delegação de alemães, de longos cabelos pelos ombros, oferecendo-se também para justarem nas bodas da imperatriz.

O dia seguinte, 15 de Outubro, foi todo ele preenchido, de manhã até à noite, com uma completa representação teatral, talvez das primeiras, de carácter profano, apresentadas na corte, e que Mário Martins considera bem mais rica que o Auto Pastoril Castelhano de Gil Vicente ${ }^{46}$. Resumi-la é empobrecê-la,

Leonor de Portugal..., p. 31.

${ }^{43}$ Sousa Viterbo, "D. Leonor de Portugal...", Archivo Historico Portuguez, VIII, pp. 41 -42,46, publica justamente algumas cartas de perdão e quitamento outorgadas pelo monarca nessa ocasião.

"Leonor de Portugal..., p. 33. E foi durante este período - de 22 de Agosto a 29 de Outubro de 1451 - que $D$. Leonor encomendou diversos panos, peças de ourivesaria e outros objectos que orçaram a 80000 reais, que o seu tesoureiro Diogo Dias dispendeu, e ao qual D. Afonso $\mathrm{V}$ passa carta de quitação, a 8 de Novembro de 1451. Esta carta, muito interessante, porque relata os diversos bens móveis adquiridos pela infanta, foi publicada por Sousa Viterbo, "D. Leonor de Portugal...", Archivo Historico Portuguez, VIII, pp. 34-35.

A. H. de Oliveira Marques resume-os, mas com bastante pormenor, na obra, A Sociedade Medieval Portuguesa. Aspectos da vida quotidiana, $2^{a}$ ed., Lisboa, Sá da Costa Editora, 1971, pp. 206-208.

${ }^{46}$ Mário Martins estuda este entremês, com detalhe, no seu artigo "Representações teatrais, em Lisboa, no ano de 1451", in Estudos de Cultura Medieval, Lisboa, Editorial Verbo, 1969, pp. 35-44. 
porque só na encenação ela colhe toda a sua beleza e magia. Digamos, porém, brevemente, que o entremês, ocorrido em vários espaços, seguindo sempre os espectadores para os lugares e palcos dos actores, teve sete quadros. No primeiro teatralizou-se a eleição de Frederico III, pelos sete eleitores do Sacro Império Romano-Germânico. No segundo encenou-se a eleição, pelo bispo de Colónia e demais eleitores, de Frederico para imperador do Sacro Império Romano. No terceiro figurou-se o Papa e seus cardeais coroando o imperador e a imperatriz. No quarto, mais espectacular em efeitos cénicos, em frente da Sé, o bispo e a clerezia abençoaram a imperatriz, com belas palavras, enquanto do cimo de uma alta torre da igreja descia um anjo com uma coroa de ouro para a coroar, voando depois um outro da janela da torre, que, vindo simbolicamente do Paraíso, carregava um açafate dourado com rosas, que lançava sobre a cabeça da Imperatriz, predizendo-lhe a sua geração terrena e a flor da virtude, a merecer, no céu, a eterna beatitude. Na quinta parte desta representação dramática, vista por cerca de vinte mil pessoas, ouviu-se um discurso por um doutor, louvando o imperador e sua esposa, para depois se assistir a um cortejo histórico de personagens que representavam todos os reis de Portugal até D. Afonso V, ao mesmo tempo que outro doutor encomiava "os actos de bravura praticados pela fé cristã e pelo povo, de que modo e quantas vezes se haviam exposto contra bárbaros, sarracenos e infiéis, e com a ajuda de Deus tinham alcançado vitória" ${ }^{47}$. E ao escutar-se a história do infeliz martírio do infante D. Fernando, correram as lágrimas nos rostos das gentes, aderindo o narrador afectivamente a este clima, afirmando "creio piamente que ele é um dos salvandos" ${ }^{48}$. No sexto quadro, agora de novo religioso, apresentaram-se perante a Imperatriz três anjos portadores de um crucifixo, de um ramo verde e de uma pomba, símbolos das três virtudes teologais, que exortavam D. Leonor a perseguir as virtudes da Fé, Esperança e Caridade na vida conjugal. Descendo à praça da cidade, deslumbravam-se os olhos numa fonte artificial, que derramava água cor de rosa, e num horto de exóticos animais selvagens. Na última cena, treze profetas desfilaram perante a infanta predizendo-lhe todos os bens e prosperidades. E ao fechar do dia, correndo as cortinas sobre os diversos actos, o sonho e o encanto seriam cortina aberta por dentro do coração dos lisboetas!

Mas logo estes, no dia imediato, folgaram em danças e vibraram com a popular tourada, correndo-se seis touros bravos, sendo dois deles mortos e distribuídos por todos. A 16 de Outubro houve um pomposo desfile militar em 
que participou o próprio monarca, para, no dia imediato, se seguir um outro mais mesclado de cristãos, mouros, selvagens e judeus que criavam o ambiente para o repto lançado ao rei de Portugal para combater, desenrolando-se então um torneio entre ele e o infante D. Fernando, que rematou com a passagem de um exótico elefante e a figuração de vários animais mitológicos - o veado, o unicórnio, o touro, o leão, o capricórnio, o urso - e, por fim, os justadores com os respectivos senhores.

Longe de chegarem ao fim, as festividades do casamento prosseguiram a 18 e 19 de Outubro com o desfile de um horrível dragão e outras momices, além de jogos de canas, premiando a infanta de Portugal, ricamente, os vencedores. No dia 20 figurou-se na praça lisboeta uma caçada com os imprescindíveis cães e animais selvagens, como um leão, um urso e um javali, e com os respectivos caçadores equipados com as suas armas. No outro dia houve mais jogos de canas e representou-se a vinda do próprio rei de Tróia, com os seus três filhos, Heitor, Priamo e Ajax, para honrar os esponsais reais com as suas artes guerreiras. A 22 de Outubro tiveram lugar combates entre pagãos e sarracenos, que, no dia imediato, se transmutaram em cantos e danças populares de cristãos, mouros, judeus, etíopes e indígenas das Canárias para, no outro, transbordarem as mesas do palácio real em alimentos e se encherem as salas de música, canto, dança e folia, enquanto Lisboa, toda ela se iluminava. O exótico e o mítico, a história e a fantasia, as novidades das recentes conquistas e as práticas dos velhos ideais, os divertimentos eruditos e as folias populares, o sagrado e o profano, deram vida a estas alongadas festividades que anunciavam já a modernidade do Renascimento ${ }^{49}$. No remate destes variegados e desmultiplicados festejos seculares, celebrou-se, no dia 25 de Outubro, uma missa solene na catedral, ricamente ornada para o efeito, em que os reis e infantes, comemorando o acto, ofereceram valiosos presentes à Igreja, havendo solene pregação, para no final o seu oficiante, o bispo de Ceuta, ter benzido a noiva.

E, no fim da festa, a tristeza da partida. No átrio da igreja uma multidão quis ainda lançar um derradeiro olhar à sua infanta, agora imperatriz. E ela, num gesto de despedida, ajoelhou-se à porta da Sé, rogando a protecção de S. Vicente para a aventura da viagem e de uma vida outra. Desceu a infanta, em procissão, até à ribeira, acompanhada dos irmãos e irmãs, de parentes e de muita fidalguia. O povo, que enchia a praia, chorava a partida da sua infanta.

` Ana Maria Alves, As entradas régias portuguesas. Uma visão de conjunto, Lisboa, Livros Horizonte, s.d., p. 21 afirma que, pela primeira vez, nestas festividades, se figura o homem silvestre, fruto da experiência africana, de largo impacto, futuramente, na imaginação e divertimentos renascentistas. 
Mas não partiu $\operatorname{logo}$ D. Leonor e a sua comitiva ${ }^{50}$, esperando, na sua carraca italiana, de nome Doria, ${ }^{\text {st }}$ que passassem os ventos contrários que então se levantaram. Neste contratempo consolava-a todos os dias o rei, seu irmão, que, por fim, dela se despediu e a recomendou, sob juramento de fidelidade até à morte, a toda a tripulação do navio e ao seu capitão-mor, o marquês de Valenç $\mathrm{a}^{52}$.

$\mathrm{Na}$ véspera da partida a infanta foi a terra com as suas damas e, numa solitária capela dedicada à Virgem, confessou-se, ouviu missa, comungou e rezou. Aí tomou uma frugal refeição de pão, peixe e fruta. No dia da largada, 5 de Novembro, um sacerdote foi ao navio, e, levando o Corpo de Cristo numa píxide que lhe pendia do pescoço, ostentou-a para adoração, rezou missa e lançou uma benção. Pela barra de Lisboa, saiu enfim a esquadra, composta por duas carracas, a da infanta e a do bispo de Coimbra, D. Luís Coutinho ${ }^{53}$, cinco navios, três maiores e dois mais pequenos e duas caravelas ${ }^{54}$, que transportavam um corpo de três mil homens. E num último e muito terno gesto de adeus, D. Afonso V acompanhou ainda a sua irmã, por mar, durante três ou quatro milhas. E logo ali nasceria na princesa a saudade da sua terra natal, presunção admissível quando o capelão de Frederico III, tendo estanciado em Portugal apenas alguns

${ }^{s 0}$ Nesta comitiva figuravam, segundo Rui de Pina, ob. cit., cap. CXXX1I, D. Afonso, Conde de Ourém e Marquês de Valença, a Condessa de Vila Real, a Velha (ou seja, D. Brites de Meneses, aia de Leonor), com damas e donzelas, o bispo de Coimbra, D. Luís Coutinho, Lopo de Almeida, Conde de Abranches, Pero Vaz de Melo, regedor da Casa do Cível de Lisboa, Alvaro de Sousa, mordomo-mor, Pero de Sousa, senhor do Prado e irmão de Fernão de Sousa, alcaide de Leiria, Afonso de Miranda e Gomes de Miranda, Gomes Freire e João Freire, D. Diogo de Castelo, o Velho, Fernão da Silveira, Martim Mendes de Berredo e muitos outros cavaleiros, servidos por 580 cavalos. Confrontem-se também as informações que fornece Luciano Cordeiro, ob. cit., pp. 75-80.

${ }^{51}$ Nome que Sousa Viterbo coligiu nas informações de um tombo de propriedades em Lisboa e nos apresenta no estudo "D. Leonor de Portugal, Imperatriz da Allemanha. Notas documentaes para o estudo biographico d'esta princesa e para a historia das relações da corte de Portugal com a Casa d'Áustria", Archivo Historico Portuguez, VII, Lisboa, 1909, p. 435.

${ }^{s 2}$ Por esta sua ausência o monarca passa-lhe uma carta, a 12 de Outubro de 1451, exigindo que todas as justiças respeitassem os bens e privilégios do conde e marquês (Sousa Viterbo, "D. Leonor de Aragão...", Archivo Historico Portuguez, VIII, pp. 35-36).

${ }^{53} \mathbf{E}$ porque este bispo integra a embaixada, também Pedro Alvares Nogueira, na sua obra, Livro das Vidas dos Bispos da Sé de Coimbra, nova edição, coord. de Manuel Augusto Rodrigues, transcrição de Maria Teresa Nobre Veloso, Coimbra, Arquivo da Universidade de Coimbra Gráfica de Coimbra, 2003, pp. 194-195, nos relata, ainda que sucintamente, os esponsais de D. Leonor com Frederico III, esclarecendo ter sido João Fernandes da Silveira que mandara erguer, em Siena, o padrão com as armas de Portugal e do Imperador, que assinalava o encontro dos esposos.

${ }^{54}$ Rui de Pina, ob. cit., cap. CXXXII, refere duas carracas, seis naus e duas caravelas. 
meses, saía já encomiando o reino pela sua abundância de frutos, a amenidade dos seus lugares, como Sintra, a devoção das suas gentes, traduzida no mosteiro de S. Jerónimo (de Penha Longa), e a justiça e a paz impostas pelo soberano ao povo, contrapondo-se-lhe, talvez, no seu pensamento, a amargura da belicosa realidade do império germânico.

VIAGENS DE D. LEONOR

(1451 - 1452)

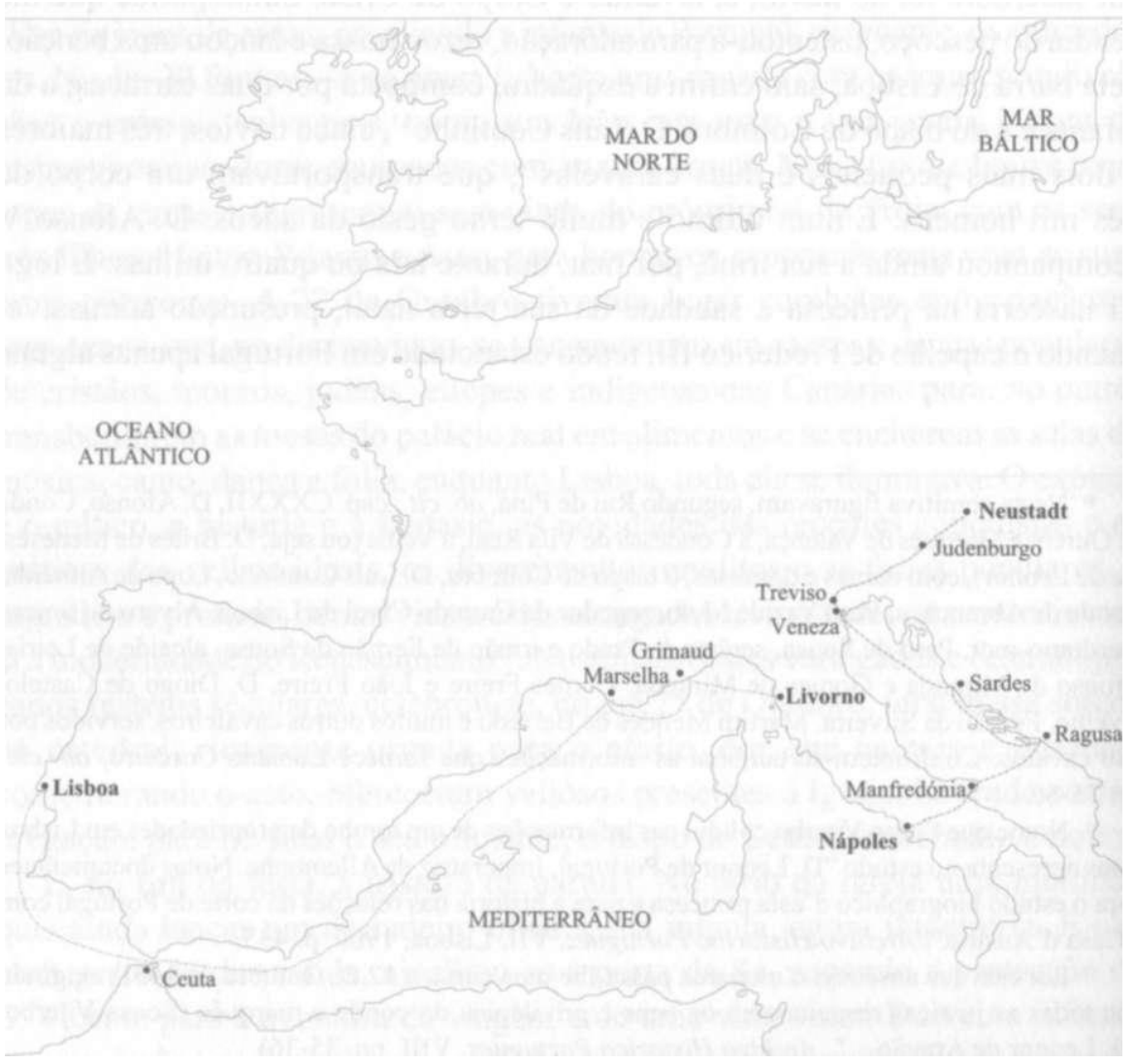

$1^{\mathrm{a}}$

Lisboa a Livorno (Novembro 1451 - Fevereiro 1452)

2a Nápoles a Neustadt (Abril 1452 - Junho 1452) 
Eis Leonor sulcando os mares, como os homens e algumas mulheres da sua linhagem, também ela lançada à descoberta - de um imperador desconhecido, que era já seu esposo, e de um reino estrangeiro, que seria a sua segunda pátria. Mas nesta incógnita e aventurosa passagem, e antes do seu final, ainda haverá um interregno, que será tempo de pomposo cerimonial e luzida festa, vivido em simbólicas, antigas e prestigiadas cidades de Itália ${ }^{55}$.

A viagem foi algo tormentosa, espreitando o perigo dos mouros em África e dos piratas nos mares. A armada aportou em Ceuta, a 20 de Novembro, aí permanecendo D. Leonor três dias para se recompor ${ }^{56}$. Fizeram-se, então, os navios de novo ao mar, a 29 de Novembro, e próximo de Valência uma caravela foi abastecer-se de mantimentos e água, passando em seguida a esquadra pela ilha de Maiorca. No golfo de Leão sofreram ventos e tempestades e avistaram até monstros marinhos, havendo necessidade de uma paragem numa ilha. Mas aí depararam com a surpresa de entreverem três navios e duas galés de piratas e ladrões, pelo que tiveram de dispersar. Aportados em Marselha, a 8 de Dezembro, levantou-se uma grande tormenta que destruiu quase todas as âncoras do navio da infanta e, em aflição, foi prometido que, amainando a procela, dois peregrinos iriam, à custa de todos, a Santiago de Compostela. Lançaram-se de novo ao mar, a 12 de Dezembro, reunindo-se a armada que dispersara com o mau tempo, e, na véspera de Natal, chegaram ao porto de Grimaud, o terceiro da viagem. Um religioso oficiou a missa natalícia no barco e houve festa, tendo-se a comitiva colectado para cumprir a promessa, sendo logo dois homens enviados a Santiago de Compostela. Estavam, uma vez mais, em viagem a 25 de Dezembro e logo no porto de Nice foram surpreendidos por piratas e ladrões com os quais tiveram de lutar e morreram mesmo alguns homens. Prosseguiram, então, passando pela Córsega e por Génova até chegarem ao porto de Leorne (Livorno). Não desembarcaram, pois não se conhecia ainda a vontade imperial sobre a escolha do porto, mas um mar alteroso a todos fez cair doentes, acabando por se decidir, a 3 de Fevereiro de 1452, enviar o capelão Nicolau Lanckmann ao imperador, que estava em Florença, saber as suas ordens.

${ }^{35}$ A sua passagem por terras italianas foi estudada por Maria Luisa Cusati, "II viaggio in Italia di D. Leonor de Portugal", in Atti delia Tavola Rotonda, Napoli 12 e 13 dicembre 1996, "II Viaggio e le Letterature Ispaniche ", a cura di Vito Galeota, Nápoles, L'Orientale Editrice, 1998, pp. 13-29.

" Rui de Pina, ob. cit., cap. CXXXII, diz que tal ocorreu a 5 de Dezembro, o que não se coaduna com as datas apresentadas na narrativa de Lanckmann. Relata ainda que a infanta foi a pé. em romaria, a Santa Maria de Africa e que o capitão de Ceuta, o conde D. Sancho (de Noronha), lhe fez honrado recebimento e as festas possíveis, com banquetes em terra e providenciou víveres e água para a armada. 
Foi-lhes, então, permitido desembarcar e uma numerosa embaixada de nobres cavaleiros, damas e donzelas ${ }^{57}$ recebeu a Imperatriz em terra, a 7 de Fevereiro, e conduziu-a a Pisa, onde descansou uma dúzia de dias ${ }^{58}$.

Leonor chegara, enfim, ao termo da viagem, após 94 dias de caminho marítimo, em que afrontou ventos e marés, temeu-se de piratas e corsários e vislumbrou mesmo monstros marinhos, conhecendo, assim, na carne, alguns dos perigos sofridos pelos seus maiores na saga descobridora. Mas a infanta, por certo de robusta compleição, chegou com saúde, a outro grande marco da sua passagem, a península itálica. Que lhe viria a ser, assim o julgamos, de gratas lembranças. E agora a visibilidade do passado, para além da crónica de Rui de Pina, surge-nos coada por duas fontes próximas mas algo antagónicas. Por um lado o relato de Lanckmann, a visão do homem da Igreja e do partido do Imperador, por outro as cartas de Lopo de Almeida dirigidas a Afonso $\mathrm{V}^{59}$, imbuídas de um espírito cortesão humorado, e sempre devotado à causa da Infanta e de Portugal. A rigorosa verdade será mediana difícil de traçar. E tão mais difícil quanto a escrita dos actos é já bem personalizada e sob ela se escondem, para sempre, os sentimentos e as vontades dos actores. Arrisquemo-nos, porém, nos escolhos da narrativa.

${ }^{57}$ Rui de Pina, ob. cit, cap. CXXXIII relata que a mesma era composta pelo duque do Saxe, dois condes, quatro barões, senhores da Alemanha e o bispo de Siena, Eneas Sílvio Piccolomini, futuro papa Pio II.

${ }^{s 8}$ Sabemos que D. Leonor, estando em Pisa, passou, a 15 de Fevereiro de 1452, uma carta de dote de casamento, no valor de 4500 ducados de ouro, a Inês Gomes, sua colaça, filha de Catarina Gonçalves, ama de D. Leonor e D. Afonso V, que era casada com Aires Gomes. Mas este dote custou a traduzir-se em acto, tendo-se conhecimento de que Inês Gomes e seu marido, Diogo Pedrosa, foram mesmo três vezes à Alemanha, depois da morte da imperatriz, reclamar esta verba, que não lhes foi paga. Então D. Afonso V, por carta de Évora de 5 de Abril de 1475, decide pagar-lhes aquele montante, mas descontando no dote da imperatriz, que ainda não havia sido entregue (Sousa Viterbo, "D. Leonor de Portugal...", Archivo Historico Portuguez, VII, pp. 435-438).

s" Publicadas por António Caetano de Sousa, Provas da História Genealógica..., t. 1, vol. 111, pp.370- 384 e por Luciano Cordeiro, ob. cit, pp. 159-177. Seguiremos, no entanto, a edição mais recente de Lopo d'Almeida, Cartas de Itália, editadas por Rodrigues Lapa, Lisboa, Imprensa Nacional, 1935. Existe também uma carta de Pero de Sousa de Prado, dada igualmente a conhecer pelos primeiros autores, mas porque tinha em vista dar infomações sobre o Marquês de Valença a D. Jaime, duque de Bragança, fornece menos indicações sobre os acontecimentos. Por amável informação da nossa Colega e Amiga Doutora Aida Fernandes Dias sabemos que a equipa de professores dos Estados Unidos, com a qual normalmente trabalha aquela especialista, encontrou em diversas bibliotecas nacionais e estrangeiras, mais cópias de cartas de Lopo de Almeida e de um outro embaixador, algumas desconhecidas, de que darão notícia na Revista de Berkeley, Romance Philologie, 57, p. 139, seguindo-se, posteriormente, a sua transcrição e estudo. 
A 19 de Fevereiro sai D. Leonor, com a sua comitiva, em direcção a Siena, sendo recebida primeiro pelo duque Alberto, irmão do imperador, e por Ladislau, rei da Hungria, e em seguida pelos cidadãos, para só depois de transpostas as portas da cidade, numa outra simbólica passagem, vir a conhecer o seu esposo. O retrato desse encontro pintou-o Pintorrichio, como mostrámos, ao abrir. Agora são as palavras que nos descobrem os gestos - apeiam-se os noivos ao avistarem-se, ouvem-se discursos, o bispo de Siena dá-lhes a cruz a beijar. Mas onde se desvendam as emoções? Lanckmann diz que o Imperador abraçou Leonor e o pintor deixa na imagem o enlace das mãos, que Lopo de Almeida só descreve à porta da Sé, enquanto Rui de Pina diz que a imperatriz quis beijar a mão do seu esposo, o que ele não consentiu. Mas que sentimentos atravessariam D. Leonor ao conhecer o seu esposo? E Frederico terá, na verdade, vacilado perante a pequenez da sua esposa, para logo depois se deixar atrair pela sua beleza meridional e temperada conversação? ${ }^{60}$ Nunca o saberemos.

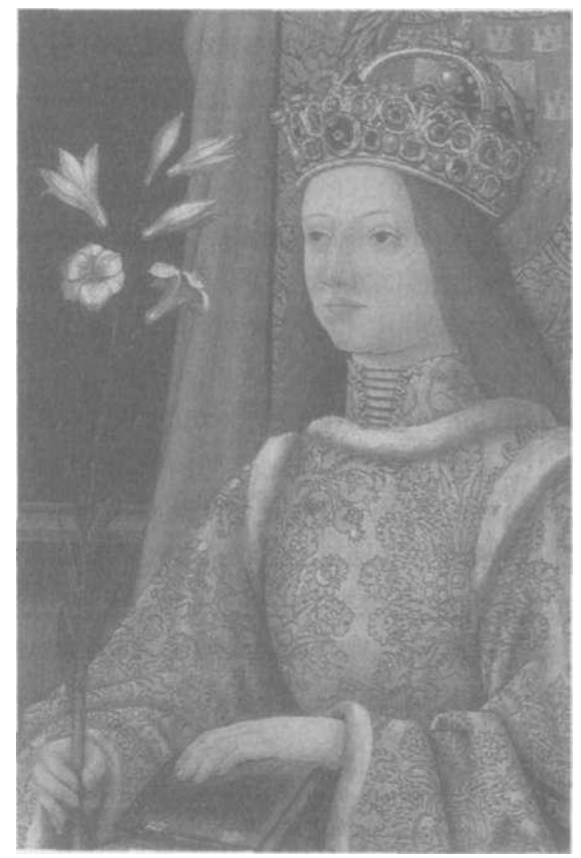

Retrato de D. Leonor

${ }^{60}$ Antonia Hanreich, "art. cit.", p. 19. Luciano Cordeiro, ob. cit., p. 41 diz que ele teria mais de dois metros de altura, o que marcaria um grande contraste com a infanta, mas acrescenta que as italianas e portuguesas, pela sua cor, eram muito apreciadas na Europa e principalmente na Alemanha. 
O bispo de Siena, esse, se escreveu com verdade, ficou cativado pela portuguesa infanta que assim descreve, física e intelectualmente:

"uma donzela de estatura mediana, de dezasseis anos de idade, testa grande, olhos muito negros e luminosos, boca pequena, faces harmoniosamente rosadas, pescoço branco, uma figura em tudo formosa e sem qualquer defeito ... verdadeiramente distinta na beleza do corpo, possuía as mais notáveis qualidades de espírito; donzela de família real, falava sem intérprete, emitia opiniões ponderadas, respondia com prudência, tudo dispunha de forma adequada, em qualquer domínio mostrava posturas reais..." ${ }^{61}$.

Já Lopo de Almeida antipatizou com Frederico, esboçando-lhe um perfil moral de homem pouco decidido, no amor como na guerra, e avarento ${ }^{62}$. Seriam os olhos da razão a sopesá-lo que não talvez os olhos do coração da infanta, que o devia amar e respeitar, como lhe mandava a Santa Madre Igreja. Certo é que, depois deste primeiro encontro, e por longos dias, D. Leonor só ocasionalmente foi vendo o seu esposo. Alojaram-se separadamente em Siena e, por percursos distintos, chegaram também aos arredores da Cidade Santa para, no dia 8 de Março, as duas comitivas nela entrarem conjuntamente com todo o aparato de indumentárias, música e cânticos. Recebeu-os o papa à porta de S. Pedro, tendo os esposos entrado na igreja, ao som de órgão e cânticos de acções de graças, para elevarem uma prece no altar-mor. Este acolhimento festivo e as honras que se lhe seguiram seriam, em boa parte, o agradecimento público do Papa ao imperador que o sustentara no pontificado e conseguira mesmo que o cismático Félix V resignasse à dignidade pontifical e acatasse a sua autoridade ${ }^{63}$.

Por vários dias, cada um no seu palácio, aguardaram os acontecimentos que se deviam seguir. Chegou o primeiro na Quinta-feira, 16 de Março de $1452^{64}$, em que Nicolau V devia abençoar o matrimónio do casal. Segundo Lopo de Almeida houve, logo no início, incidentes de protocolo, sendo D. Leonor conduzida a S. Pedro por dois duques e mais umas escassas duas dezenas de alemães, quando a sua dignidade exigia a presença do irmão do Imperador ou do rei da Hungria. Confortá-la-ia o cortejo de toda a embaixada portuguesa a acompanhá-la.

Iniciado o cerimonial, o imperador e sua esposa, de joelhos, beijaram o pé e as mãos do Santo Padre, que retribuiu a saudação beijando na face o imperador. Nicolau V iniciou então as orações de bênção e benzeu os anéis que colocou

61 Tradução livre, a partir dos extractos latinos citados por Luciano Cordeiro, ob. cit., pp. 40-41.

${ }^{62}$ Confrontem-se as referências ao carácter do imperador em Antonia Hanreich, "art. cit.", p. 4 e Luciano Cordeiro, ob. cit, p. 59.

${ }_{63}$ Pedro Alvares Nogueira, ob. cit., p. 163.

${ }^{6}$ Rui de Pina, ob. cit., cap. CXXXIII, antecipa para 15 de Março. 
nos dedos dos esposados, perguntou a ambos se casavam de livre vontade e, obtendendo o respectivo assentimento, mandou que se beijassem nas faces e lançou-lhes a bênção, seguindo-se o ofício divino. Frederico III e D. Leonor estavam, agora, casados à face da Igreja, ao seu mais alto nível, e por ela abençoados. Mas não houve festa, nem consumação do matrimónio. Por ser Quaresma, dizem as fontes ${ }^{65}$.

No Domingo seguinte, 19 de Março ${ }^{66}$, teve lugar em S. Pedro o solene acto de sagração e coroação. D. Leonor, de belos cabelos longos e ondeados, enfeitados com uma fita de ouro que lhe oferecera o rei seu irmão, foi ungida nas espáduas e no braço direito pelo Papa. Iniciou-se a missa, trazendo o Papa na mão uma rosa de ouro, por ser dia de Nossa Senhora da Rosa e, ao Evangelho, foram coroados pelo Santo Padre o imperador e a imperatriz, que acrescentou a Frederico as suas demais insígnias e objectos simbólicos - a espada, o ceptro e o globo. Comungaram ambos pela mão do Sumo Pontífice e abandonaram S. Pedro com as suas coroas na cabeça.

D. Leonor é agora imperatriz, de facto. A Medalha da Rosa, então cunhada, revelá-la-á, quase esfíngica, nessa magestade cesárea ${ }^{67}$, com a sua açucena na mão. Justamente, à moda cortês da época, D. Leonor, por certo já como imperatriz, possuía empresa própria, que tinha como corpo um pé de açucena, e por alma o moto "Per bon amor"68. Mas, após este soleníssimo acto, de novo, Leonor, se vê afastada do seu marido, que, separado dela, estancia em S. João de Latrão ${ }^{69}$, onde, segundo Lopo de Almeida se ceou com pouca abundância de ornamentos e muita falta de protocolo, pois como desabafa, "estes homens sam barbaros e bestas" ${ }^{10}$. Alguns dias a mais decorridos e a estadia em Roma termina. Leonor guardaria para si a grata lembrança de ter pisado terra da Cidade

${ }^{65}$ Idem, ibidem, cap. CXXXIII.

"Rui de Pina, ob. cit., cap. CXXXIII, aponta o dia 28 de Março.

${ }^{67}$ Luciano Cordeiro, ob. cit.,p. 40. Na legenda dessa medalha está escrito: "Leonor Augusta Frederici Imperatoris Uxor". Uma descrição um pouco diversa e mais completa, nos apresenta o Catálogo "Os Descobrimentos Portugueses e a Europa do Renascimento" XII Exposição de Arte. Ciência e Cultura, Lisboa, Presidência do Conselho de Ministros, 1983, p. 182.

${ }^{68}$ Henrique Avelar e Luís Ferros, "As empresas dos Príncipes da Casa de Avis". in "Os Descobrimentos Portugueses e a Europa do Renascimento" p. 230.

${ }^{69}$ Rui de Pina, ob. cit., cap. CXXXIII, refere que ambos seguiram para S. João de Latrão, por certo equivocando-se. Pelo caminho, e depois no dia seguinte, o Imperador armou muitos nobres cavaleiros, contando-se entre eles, segundo Rui de Pina, o duque Alberto, seu irmão, e o rei da Hungria, Ladislau (cfr. Luciano Cordeiro, ob. cit., p. 39).

70 Lopo de Almeida, Cartas de Itália, p. 19. 


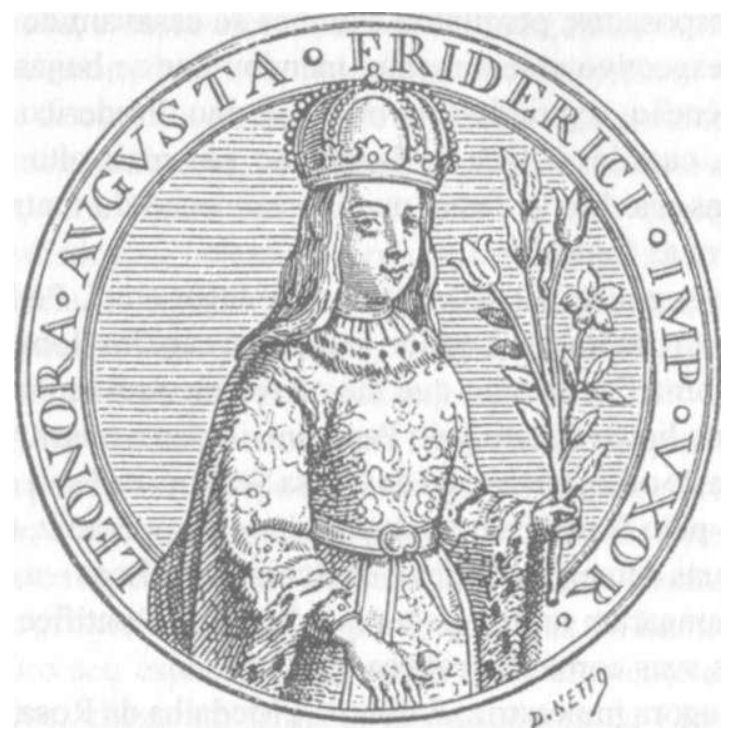

Medalha da rosa

Santa, destino de tantos peregrinos, nela havendo recebido as máximas honras da bênção papal do seu matrimónio e de ser ungida e coroada imperatriz, na Igreja de S. Pedro, pelo Sumo Pontífice. Recebera ela, afinal, o que nenhum rei da dinastia de Avis lograra, a sagração e coroação real, que, mesmo a ter existido, nunca poderia vir pela mão do $\mathrm{Papa}^{71}$. Mas Leonor tê-la-ia assumido como mais uma glória para a sua linhagem e para o seu reino.

Fechada esta página da sua longa saga matrimonial, o caminho seria para o reino de Nápoles. Talvez tenha partido a imperatriz a 23 de Março $^{12}$ e o percurso parece ter sido agradável, sobretudo em terras do rei de Aragão. E já nas cercanias de Nápoles, muitos grandes vieram ao seu encalce para, a uma légua da cidade, deparar com o seu tio, o irmão de sua mãe. Este, quando a viu, muito afectivamente, tirou o sombreiro, abraçou-a e beijou-a e, depois de cumprimen-

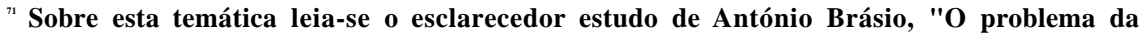
sagração dos monaracas portugueses", Anais da Academia Portuguesa da História, II." série, vol. 12. Lisboa, 1962, pp. 21-49.

"Esta é a data que apresenta Lopo de Almeida (Provas, t. I, vol. III, p. 378). Já Lanckmann refere que o imperador participou em certos actos a 25 de Março, para dois parágrafos depois afirmar, "seguiu-se a partida da Senhora Imperatriz", o que nos deixa algumas dúvidas. Por sua vez Rui de Pina, ob. cit., cap. CXXXIII, coloca essa partida a 27 de Março. 
tar as cerca de vinte damas que a acompanhavam, acercou-se de D. Leonor e disse-lhe: "que lhe parecia que tomara ella todo o bem de sua madre" ${ }^{13}$. Era a voz do sangue a falar, porque olhando para a filha de Leonor de Aragão, agora imperatriz, o rei de Nápoles sentiria que a memória de sua irmã se desagravava, enaltecendo-se um ramo da sua descendência. Por isso, o rei de Aragão e Nápoles, que era já dado ao prazer e ao divertimento, não lhe faltando mesmo a companhia de senhoras de fama duvidosa, fez da presença dos esposos no seu reino um tempo de festa, de prodigalidade e de ostentação. Houve banquetes, em que a par da comida e da bebida, os serões eram animados com dança e música, brilhando o palco e os actores à luz irradiante de muitas velas. Ocorreram justas, jogos de canas e caçadas a animais selvagens. Tiveram lugar desfiles de cavaleiros e donzelas bem ataviadas por ruas ornamentadas com belos e ricos panos e até mesmo com reluzentes montes de moedas de ouro e prata. Os dias felizes e despreocupados, entre eles as próprias festividades da Páscoa, correriam velozes, na alegria e no divertimento.

Nas oitavas da Páscoa, passado todo o tempo de interditos, o Imperador decidiu consumar o matrimónio. Lanckmann é discretíssimo, como seria de esperar de um clérigo, declarando que "preparado o quarto nupcial muito omamentadamente, para o sereníssimo senhor imperador e sua senhora, esposa e donzela, eles ficaram a sós"74. Por sua vez Lopo de Almeida ${ }^{75}$ não se poupa a pormenores. Descreve uma primeira cerimónia da ida de D. Leonor à câmara de Frederico para os esposos se beijarem, mas logo retornando a Imperatriz à sua câmara para aí esperar o esposado. Mas não foi ele que apareceu, antes dois condes em seu nome, para conduzir a virgem esposa. Leonor, "entrincheirada" no seu domínio privado, recusou-se. As embaixadas repetiram-se por cinco ou seis vezes. Até que o Imperador, em pessoa, veio rogar a presença da sua esposa e conduzi-la ao leito nupcial. Este pormenor da segunda carta de Lopo de Almeida, à primeira vista pitoresco, parece-nos de um vasto alcance, se o relacionarmos com o incidente, descrito na primeira, em que, estando-se em Roma, toda a embaixada portuguesa considerou que a infanta estava a ser desconsiderada por ser conduzida, abaixo da sua dignidade, apenas por dois duques, até à igreja de S. Pedro, onde se encontrava o imperador. Leonor, aconselhada pelos grandes de Portugal, fê-lo então saber a Frederico III, mas este reiterou a sua ordem. A infanta obedeceu, mas teria guardado a mágoa.

${ }^{13}$ Lopo de Almeida, Cartas de Itália, p. 23.

Leonor de Portugal..., p. 81.

${ }^{75}$ Lopo de Almeida, Cartas de Itália, p. 29. 
Esperou, pacientemente, o ensejo da desforra ou, pelo menos, de fazer sentir a desconsideração. E eis que à beira da consumação carnal do seu matrimónio o momento se lhe ofereceu. Certa da sua vitória, negou-se a ser conduzida por dois condes à câmara do imperador. Só ele próprio, como dignidade máxima, seria o mensageiro apropriado para uma imperatriz. E assim foi feito.

Leonor, esposa prometida por palavras de futuro e presente, a esposa virgem abençoada pelo papa, é agora a esposa carnal de Frederico III. Dele recebeu, pois, na manhã seguinte a esse acto, a renda da câmara, contida no contrato. Mas também ainda nesse dia, ou pouco depois, o imperador partiu para Roma. Leonor será ainda acarinhada por seu tio com presentes, entre peças de brocado e sedas, ricas vestes forradas de penas, um firmai de diamante e mesmo o saldar de uma sua dívida ${ }^{76}$.

Indubitavelmente a Itália ficaria para sempre gravada na vida da filha de D. Duarte. Durante o seu pregrinar na Cidade dos Homens, por entre os seus afectivos lugares de memória, Leonor guardaria a recordação de três cidades italianas. Siena evocar-lhe-ia o encontro primeiro com o seu esposo. Roma recordar-lhe-ia a magnificência e a dignidade de ter sido coroada imperatriz. Nápoles desdobra-se-ia em imagens e sentimentos de família, de carinho e de festa e em vivências íntimas de mulher. Nesta última cidade, ainda donzela, reencontraria, de novo, um pouco do seu perdido país natal. Para depois, feita dona, desabrochar em toda a sua maturidade, pois como relata ao monarca Lopo de Almeida "ella parece milhor outro tanto, ella sabe muito mais, acontenença muito milhor, de guisa que com muita honestidade, graveza e repouso he muito graciosa, fala muito milhor e sabe fazer gasalhado a todos e outras cerimonias per seu ponto", pelo que ricos e pobres a bendizem ${ }^{77}$.

Mas o encanto estava a chegar ao fim. Porque, na realidade, as fontes históricas que nos chegaram sobre D. Leonor desvendaram-nos como que o acto central de um qualquer conto infantil - um imperador de terras longínquas buscou uma noiva num pequeno reino dos confins do mundo. A bela noiva foi conduzida até ao seu prometido e com ele foi coroada Imperatriz. Para em seguida, por entre grandes festas, se unirem. E... espera-se que se diga "e foram muito felizes". Não parece que assim possa ser.

${ }^{76}$ Lopo de Almeida estima que só com a infanta o rei de Aragão teria gasto, sem contar a comida. 10 mil cruzados, e com toda a comitiva imperial 90 mil. Rogava, pois, a Afonso $\mathrm{V}$ que muito lhe agradecesse até porque ele assim o reclamava e exigia: "porque me parece que quer que lho nom deixem de dizer e ainda cedo; algum bem, se o faz e se lho outrem não diz, busca elle maneira de o dizer e soelhar" (Lopo de Almeida, Cartas de Itália, p. 30).

"Lopo de Almeida, Cartas de Itália, pp. 32-33. 
Leonor parte de Nápoles, a 24 de Abril de 1452, para, num percurso por terra e $\operatorname{mar}^{78}$, chegar a Neustadt, na Áustria, a 19 de Junho. Da viagem recordaria, por certo, com agrado, a sua recepção e estadia de descanso em Veneza ${ }^{19}$. Mas chegada a Neustadt, não pôde aí permanecer, porque na Áustria reinava um clima de rebelião dos grandes contra o imperador, havendo-se refugiado na Estíria. E a guerra acompanhou os anos de Leonor como imperatriz da Alemanha. Acrescentando-se-lhe a dor da morte de muitos dos seus filhos, que a diferença de mentalidades e comportamentos entre os dois cônjuges ainda mais agudizaria ${ }^{80}$.

O quadro da sua vida carrega-se de negro. Nasce-lhe, em Neustadt, um filho varão, Cristóvão, a 16 de Novembro de 1455, para falecer quatro meses depois. De novo grávida, assiste, nessa mesma cidade, à ratificação da eleição de Frederico, por morte de Ladislau, para rei da Hungria e herdeiro da coroa de Santo Estêvão, para, a 22 de Março de 1459, sendo já imperatriz e rainha da Hungria, Dalmácia e Croácia, lhe nascer e vingar, talvez sob este bom presságio, Maximiliano, o futuro imperador. Dará ainda à luz, em Viena, a 3 de Novembro de 1460, Helena, que morre três meses depois. Em 1465, a 16 de Março, em Neustadt, nasce Cunegundes e, finalmente, no ano seguinte, a 9 de Agosto, vem ao mundo João, que morre antes de completar seis meses. Leonor,

${ }^{78}$ Por terra atravessou o reino da Sicília e chegou a Manfredónia, a 3 de Maio. Dois dias depois a imperatriz, com os seus barões e cavaleiros, fez uma peregrinção à igreja de $S$. Miguel, no monte de Santo Ângelo, onde se rezou missa e houve festa. Daí a comitiva embarcou, em duas galés, para, navegando alguns dias, entrar no reino da Dalmácia e parar não longe de Ragusa. No outro dia chegaram à cidade de Sardes, onde a imperatriz e seu séquito desembarcaram e ouviram missa. Alguns dias depois alcançaram, por fim, o porto de Veneza, reunindo-se nesta cidade os esposos. Após alguns dias de descanso, ambas as comitivas empreenderam a viagem por terra até Pordenone, passando depois por Treviso e chegando a Judenburg. Entraram, no dia 19 de Junho de 1452, em Neustadt, sendo recebidos, com honra e reverência, pelo povo da cidade.

79 Ainda na Manfredónia, já o rei de Aragão mandara a preceder a comitiva imperial dois navios com cavalos, mulas, servidores e mais coisas necessárias. Desembarcada em Veneza, a imperatriz e sua comitiva recebeu hospitalidade, por três dias, no Mosteiro de S. Nicolau. A 18 de Maio, o duque de Veneza e seus maiores vieram-na buscar, conduzinda-a a galés e navios aparamentados, aos quais se juntaram os do imperador e de um vasto séquito, estimado em cinco mil navios. Na cidade foram levados até ao palácio que lhes estava destinado, ao som de trombetas e charamelas, repicando os sinos das igrejas e manifestando-se a alegria do povo. Visitaram o tesouro de $\mathrm{S}$. Marcos e demoraram-se sossegadamente na cidade alguns dias, afirmando Lanckmann "que se alguma vez o Senhor Jesus Christo viesse, com S. Marcos, às terras dos Senhores de Veneza, dificilmente lhe concederiam tanta reverência e honras" (Leonor de Portugal..., p. 87).

${ }^{\text {so }} \mathrm{Na}$ realidade, parece que Frederico III culpava D. Leonor pela morte dos filhos, acusando-a de lhes dar uma alimentação pouco salutar com doces portugeses (Antonia Hanreich,"art. cit.", p. 22). 


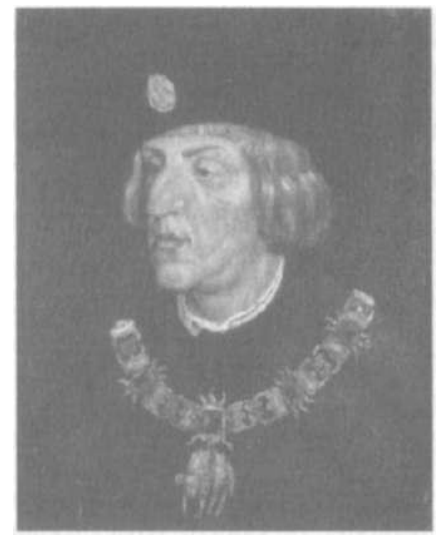

Maximiliano I, imperador da Alemanha

contemplada com cinco filhos, viu porém desaparecer a sua maioria, para se quedar apenas com dois, Maximiliano e Cunegundes ${ }^{81}$.

Diz-se ainda que, por entre as rebeliões e guerras movidas contra o Império, numa arremetida sobre Viena, onde estava a imperatriz e o seu filho Maximiliano, terá sido ela a liderar a resistência e a salvar a cidade ${ }^{82}$. Pressente-se, aliás, que o espírito algo dissimulado e calculista do seu marido, que em certos momentos bélicos cruciais mais esperava e negociava do que entrava em acção, não era partilhado por Leonor. Ela era herdeira dos portugueses de Aljubarrota e Ceuta e propendia para a frontalidade do ataque e defesa, porque lhe corria nas veias sangue de reis guerreiros. Aliás, naquele momento crítico, teria mesmo dito ao pequeno Maximiliano que se ele agisse como seu pai lamentaria tê-lo concebido para herdar o trono ${ }^{83}$. E do seu longínquo reino, que sabia repelir dominadores estranhos e lutar pelos valores cristãos, terá falado ${ }^{84}$ muitas vezes ao seu pequeno filho Maximiliano, incitando-o a perseguir tais ideais ${ }^{85}$. Mas pouco lhe poderá

${ }^{s t} \quad$ Leonor de Portugal..., ,pp. 91-93.

${ }^{82}$ Veja-se Luciano Cordeiro, ob. cit., p. 87; e Antonia Hanreich, "art. cit.", pp. 21-22.

${ }^{83}$ Luciano Cordeiro, ob. cit, p. 80, Antonia Hanreich, "art. cit.", p. 22.

${ }^{84}$ E. A. Strasen, A. Gândara, "art. cit.", pp. 81-82, diz que Leonor nunca deixou de ser profundamente portuguesa, querendo-lhe muito os alemães.

${ }^{85} \mathrm{E}$, na verdade, parece que Maximiliano tinha grande estima por seus primos D. João II e D. Manuel e arvorava sempre as armas de Portugal ao lado das de Espanha. Para além disso, Maximiliano era casado com Maria da Borgonha, filha de Carlos, o Temerário e neta de Isabel, duquesa da Borgonha, tia de sua mãe. $O$ imperador terá mesmo oferecido a $D$. Leonor, mulher de D. João II, um belo quadro que se intitulava "Panorama de Jerusalém" e um Santo Sudário bordado em seda preta. Finalmente, no túmulo que para si encomendou, figurava o Infante Santo, D. Fernando, tio de sua mãe (E. A. Strasen, A. Gândara,"art. cit.", pp. 79-81, 86-87). 
ter transmitido, ensinando-lhe, porém, as primeiras letras ${ }^{86}$, uma vez que privou apenas oito anos com o seu filho, embora se diga que ele a contava entre os bem-aventurados ${ }^{87}$. De facto, depois do último parto adoeceu, passando mesmo algum tempo nas termas de Baden, para, a 3 de Setembro de $1467^{88}$, abandonar este mundo, ao fim de nele ter peregrinado trinta e três anos. E como mãe dolorosa quis reunir os seus restos mortais aos dos filhos, fazendo-se sepultar no convento de Cister em Neustadt, onde eles repousavam, na expectativa de gozar a sua eterna companhia na Jerusalém Celeste. Imortalizou-a na pedra de mármore do seu túmulo um escultor, que a apresenta, em toda a sua dignidade e atributos imperiais, compondo-lhe um retrato de beleza serena ${ }^{89}$.

Como antes anunciámos, o final da história dos belos esponsais entre um imperador e uma imperatriz não foi de encanto e felicidade. Se com os relatos desses esponsais vivemos por dentro do sonho, da festa, da beleza, já com as poucas notícias que nos chegaram sobre o tempo que lhes sobreveio nos quedamos, algo defraudados, perante uma implacável e dura realidade.

A vida de Leonor iluminara-se para se ensombrar. Algo triste, mas serena, terá vivido, até aos seus dezasseis anos, com suas irmãs, em terras portuguesas. Desassossegou-se depois, perante um futuro a haver, desde que se assinou o seu contrato nupcial. Participou de uns longos esponsais, repartidos por cenários vários de terra e mar, de festa e fé, ou de receio e medo, que atingiram o seu clímax de pompa e alegria em terras italianas. Protagonizou, por fim, uma vida de imperatriz de um Império dividido por guerras internas e uma vida de mulher-mãe, que a fez chorar a perda de três filhos, sem o consolo de parentes e amigos ${ }^{90}$.

${ }^{86}$ Luciano Cordeiro, ob. cit.,p. 90, diz conservar-se ainda nas colecções imperais, em Viena, o alfabeto que $D$. Leonor mandou fazer, ornado de arabescos e figuras de animais com cores vivas, para ensinar a Maximiliano as primeiras letras.

Antonia Hanreich, "art cit.", p. 23.

${ }^{88}$ Meses antes de falecer, em Janeiro de 1467 , terá tido ainda a felicidade de ver chegar, proveniente de Portugal, o cavaleiro Leo von Rosmital, que lhe trouxera uma carta do rei seu irmão, sendo estas as últimas notícias que recebeu da sua terra natal. Com tal cavaleiro teria vindo um tocador de harpa, que estudara músicas e danças portuguesas, e D. Leonor quis que ele ensinasse $o$ seu filho. Era a derradeira herança da sua cultura pátria que lhe transmitia (Luciano Cordeiro, ob. cit., p. 91).

Quanto à identidade do artista, Luciano Cordeiro, ob. cit., p. 92, identifica-o com Nicolau Lerck de Estrasburgo, enquanto Antonia Hanreich, "art. cit.", p. 24, diz tratar-se do neerlandês Gerhart van Leyden. Júlio Dantas, como refere Henrique de Campos Ferreira, "art. cit.", p. 146, também o atribui a Nicolau Lerck.

${ }^{9}$ Antonia Hanreich, "art. cit.", pp. 20-21, fala apenas de uma sua servidora portuguesa na Alemanha, Beatriz, esclarecendo que também o médico do imperador, Mateus Lopes, era português. 


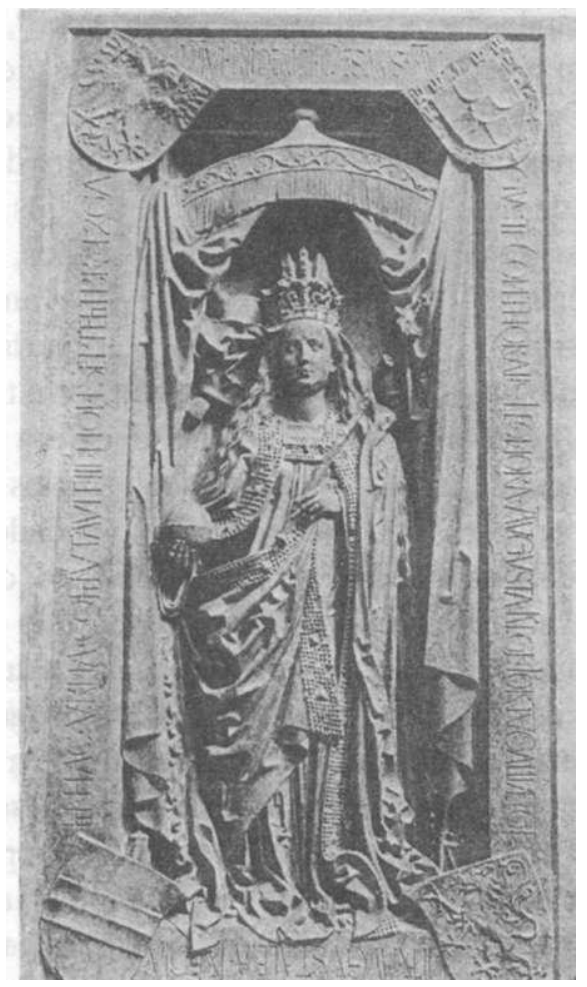

Túmulo jacente de $D$. Leonor

Leonor, como que antecipando a saga da sua linhagem e do seu reino, sonhou o Império... mas " o Império se (lhe) desfez". Todavia, nas asas do sonho, materializou-se o fundamento da reprodutiva linhagem dos Habsburgo, raiz matricial do grande imperador Carlos V, que também no reino de Portugal buscou esposa. Desta vez Isabel, a filha do Venturoso rei das Índias e da Terra de Vera Cruz, D. Manuel I. 